\title{
黄河三角洲不同淹水条件下芦苇和盐地碱蓬 调落物的分解与重金属归还特征
}

\author{
关亚楠 ${ }^{1,2}$, 白军红 ${ }^{1}$, 王 伟 ${ }^{1}$, 王大伟 ${ }^{1}$, 尹 硕 ${ }^{1}$ \\ (1. 北京师范大学环境学院, 水环境模拟国家重点实验室,北京 100875 ; \\ 2. 河北师范大学化学与材料科学学院, 石家庄 050020)
}

\begin{abstract}
摘要: 以黄河三角洲芦苇 (Phragmites australis) 和盐地碱蓬 (Suaeda salsa) 的调落物为研究对 象, 研究不同淹水条件下芦苇和盐地碱蓬调落物的分解与重金属的归还特征。结果表明:两种 淹水条件下, 盐地碱蓬调落物的失重率均高于芦苇调落物; 潮汐淹水条件下芦苇和盐地碱蓬调 落物的失重率均高于短暂淹水处理。在两种淹水条件下, 经过分解后芦苇调落物中 $\mathrm{As} 、 \mathrm{Cr}$ 和 $\mathrm{Cu}$ 的含量增加, 潮汐淹水条件下芦苇调落物的各金属含量均高于短期淹水处理。盐地碱蓬调落物 经过分解后, 各重金属含量总体上呈上升变化趋势, 潮汐淹水条件下的盐地碱蓬调落物中 As、 $\mathrm{Cu}$ 和 $\mathrm{Pb}$ 的含量均高于短期淹水处理。两种淹水条件下芦苇和盐地碱蓬调落物中的 $\mathrm{Pb}$ 和 $\mathrm{Zn}$, 在分解期间均发生了不同程度的释放。研究结果有助于理解潮汐作用对黄河三角洲芦苇和盐 地碱蓬调落物分解和重金属归还的影响。
\end{abstract}

关键词: 调落物; 淹水; 芦苇; 盐地碱蓬;分解; 重金属

调落物是指在生态系统内, 地上植物组分归还到地表面, 作为分解者的物质和能量 来源, 是维持生态系统功能的所有有机质的总称 ${ }^{[1]}$ 。调落物的分解是一系列的物理过程和 生物化学过程共同作用的结果, 包括调落物的矿化、淋溶及风化等过程。该过程将复杂 的有机物转化为简单的无机物, 在分解过程中产生 $\mathrm{CO}_{2}$ 和 $\mathrm{H}_{2} \mathrm{O}$ 以及其他养分元素的淋 失, 并释放出能量 ${ }^{[2-4]}$ 。由此可知, 植物调落物在分解过程中, 不断释放化学物质, 是生 态系统物质循环和能量流动的关键环节, 也是维持生态系统功能的主要过程之一。调落 物分解速率的变化将直接影响区域乃至全球尺度上的气候变化, 在维持生态系统结构、 功能及稳定性等方面具有不可替代的作用 ${ }^{[5,6]}$ 。

重金属污染给生物及人类带来极大的潜在危害，并具有很强的生态毒性效应 ${ }^{[7,8]}$ 。重 金属不仅难以降解，并可以通过食物链在生物体内不断富集。调落物中的重金属随分解的 进行, 被食腐屑生物食用, 或返还到河口 ${ }^{[9]}$ 。虽然 $\mathrm{Cu}$ 和 $\mathrm{Zn}$ 是植物生长必需的微量元素, 但过量的重金属富集会对植物的生长造成胁迫, 一旦重金属含量超出植物的耐受范围, 会引起植物体内代谢过程紊乱, 造成不同程度的毒害 ${ }^{[10]}$ 。湿地植物芦苇 (Phragmite australis）对重金属具有很强的吸收能力 ${ }^{[11]}$ ，但芦苇富集的重金属可通过调落物的分解归还到土 壤中。湿地水文是影响湿地生物地球化学的重要因素, 重金属在不同淹水条件下分布特征 具有显著差异, 而且水文条件可以导致温度、 $\mathrm{pH} 、 \mathrm{Eh}$ 、溶解氧浓度、盐度等环境因子的

收稿日期：2018-11-20；修订日期：2019-03-03

基金项目：国家重点研发计划项目（2017YFC0505906）；北京师范大学学科交叉建设项目（11500-312231104）; 中 央高校基本科研业务费专项基金

作者简介: 关亚楠 (1989-), 女, 河北石家庄人, 博士研究生, 研究方向为湿地生物地球化学。

E-mail: ynguan14@163.com

通讯作者：白军红（1976- ), 男, 河北无极人, 博士, 教授, 研究方向为湿地生态修复。E-mail: junhongbai@163.com 
变化, 进而影响调落物分解及其重金属含量变化 ${ }^{[12-14]}$ 。目前, 相关研究主要集中在湿地沉 积物和水体重金属污染方面，而对不同淹水条件下湿地植物残体对重金属的归还方面的 研究较少 $[7,15]$ 。

黄河三角洲地处黄河人海口, 是在咸淡水交互作用下发育而成的世界上最年轻、最 具有特色的湿地，在维系当地及周边地区生态平衡和生态安全方面有着重要而不可替代 的作用。本文对比分析黄河三角洲不同淹水条件下芦苇和盐地碱蓬（Suaeda salsa）的调 落物分解以及重金属归还的差异。研究结果有助于认识两种湿地植物调落物在分解过程 中重金属的动态变化及其对生态系统物质循环的作用，可为黄河三角洲污染防治和生态 系统健康维持提供重要科学依据。

\section{1 研究方法与数据来源}

\section{1 研究区概况}

黄河三角洲（36 $55^{\prime} \sim 38^{\circ} 16^{\prime} \mathrm{N}, 117^{\circ} 31^{\prime} \sim 119^{\circ} 18^{\prime} \mathrm{E} ）$ 位于莱州湾和渤海湾之间，是中 国暖温带最广阔、保存最完整的新生湿地系统。该地区属于暖温带半湿润大陆性季风气 候区，四季分明，雨热同期，多年平均气温 $11.7 \sim 12.6{ }^{\circ} \mathrm{C}$, 降水量为 $530 \sim 630 \mathrm{~mm}$, 蒸发 量为 1750 2430 $\mathrm{mm}^{[16]}$ 。该区的土壤类型为隐域性潮土和盐土, 土壤含盐量高, 主要湿地 植被包括芦苇和盐地碱蓬和柽柳（Tamarix chinensis）等。黄河三角洲海洋水文特征为沿 海潮汐，以半日潮为主；进人黄河三角洲地区的径流以汛期径流为主。

本研究选取黄河三角洲湿地的典型样区进行试验。包括位于受潮汐影响的近海区域 的湿地, 一天淹水两次, 时长为 8 小时; 以及每年 6-7月受到上游小浪底调水调沙影响导 致短期淹水的湿地, 一年淹水一次, 时长约为 45 天。分别选取上述潮汐性淹水和短暂性 淹水的芦苇和盐地碱蓬湿地群落作为研究样地（图 1)。

\section{2 样品采集与处理}

11 月, 采集芦苇和盐地碱蓬植株地上部分, 自然风干，去除泥土和其他植物等杂 物, 作为来年自然状态下待分解的调落物。调落物的分解实验是采用分解袋法, 分解袋 的孔径为 60 目， $20 \mathrm{~cm} \times 20 \mathrm{~cm}$ ，每袋 封装大约 $10 \mathrm{~g}$ 调落物。次年 5 月, 分 别在上述典型样地随机选取三个小 区，将芦苇和盐地碱蓬调落物分解袋 分别放置在对应样地的小区中，平铺 （下表面贴地）在土壤表面，并于 8 月和 11 月分别从每个小区随机取回 3 个分解袋，去掉泥土和其他表面杂 物, 用去离子水将样品清洗干净后, $40{ }^{\circ} \mathrm{C}$ 下烘干称重。将称重后的样品 用粉碎机磨碎, 过 20 目尼龙篮后进 行测定。

采取微波消解溶样法对测定样品 预处理，使用全谱直读感耦等离子体

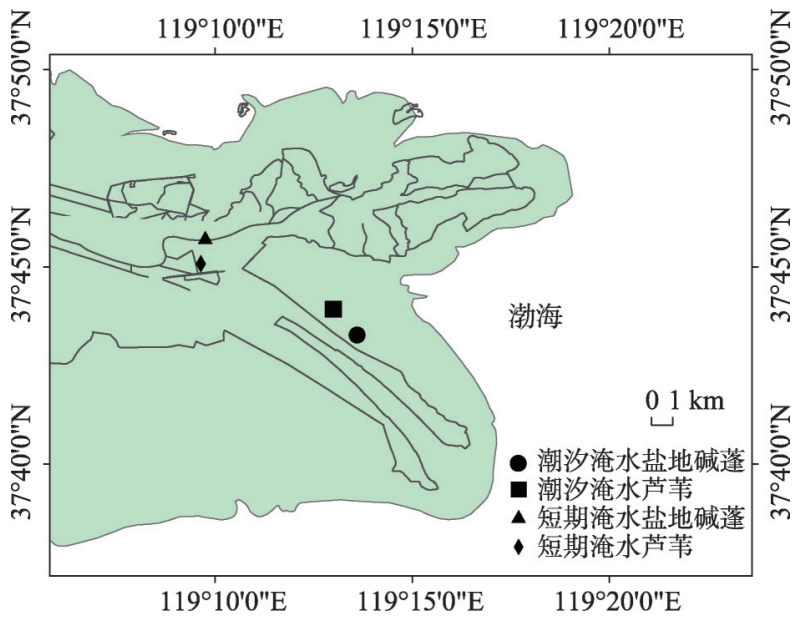

图 1 研究样地

Fig. 1 Location of the sampling sites 
原子发射光谱仪（ICP-AES法）测定 $\mathrm{As} 、 \mathrm{Cr} 、 \mathrm{Cu} 、 \mathrm{~Pb} 、 \mathrm{Zn}$ 等五种重金属的含量。使用的 标准物质（GBW07602）源于中国计量科学院，重金属回收率为 $85 \%$ 118\%。

\section{3 数据处理与分析}

调落物失重率 $R(\%){ }^{[17]}$ 表达式如下:

$$
R=\left[\left(W_{t}-W_{0}\right) / W_{0}\right] \times 100 \%
$$

式中: $W_{0}$ 为调落物的初始质量 $(\mathrm{g}) ; W_{t}$ 为分解 $t$ 时间后调落物的残留量 $(\mathrm{g})$ 。

调落物分解过程中重金属的累积或释放可用重金属净归还率 $(E)$ 表示:

$$
E=\left[\left(e_{0}-e_{i}\right) / e_{0}\right] \times 100 \%
$$

式中: $e_{0}$ 为调落物重金属的初始质量 $(\mathrm{g}) ; e_{i}$ 为调落物重金属在 $i$ 时刻的质量 $(\mathrm{g})$, 若 $e_{i}<$ $100 \%$ ，表明淍落物重金属在分解过程中发生了归还，反之则发生了吸附和积累。

运用Origin 2018 软件对数据进行作图, 采用SPSS 23.0 软件对不同调落物的失重率 以及各重金属含量作单因素方差分析, 对调落物残留量和重金属含量与淹水条件和分解 时间进行双因素方差分析，若 $P<0.05$, 则表明具有显著性差异。

\section{2 结果分析}

\section{1 调落物失重率的变化}

不同淹水条件下芦苇和盐地碱蓬的调落物的失重率均随时间推移不断增加，盐地碱 蓬调落物的失重率均高于芦苇调落物 $(P<0.05)$ （图 2)。在潮汐淹水条件下的芦苇和盐地 碱蓬调落物第一阶段分解速率较第二阶段高, 而短期淡水淹水条件下, 两种调落物两个 阶段分解速率差异不明显（ $P>0.05 ）$ 。经过 180 天分解后, 芦苇调落物在潮汐淹水和短期 淹水条件下的失重率分别为 $25.21 \%$ 和 $19.22 \%$ ，二者之间不存在显著性差异（ $P>0.05 ＼mathrm{~ ; ~}$ 在潮汐淹水和短期淹水的盐地碱蓬调落物 失重率分别为 $37.08 \%$ 和 $28.49 \%$ ，且二者之 间存在显著性差异 $(P<0.05)$ 。上述结果表 明, 盐地碱蓬调落物在两种淹水条件下失 重率均高于芦苇 $(P<0.05)$; 潮汐淹水条件 下芦苇和盐地碱蓬的失重率均高于短期淹水 处理。采用双因素方差分析检验了淹水条件 和分解时间对芦苇和盐地碱蓬凋落物的残余 质量的影响（表1、表2）。结果显示，不同 淹水条件和分解时间对芦苇和盐地碱蓬的 分解速率都有显著性影响 $(P<0.05)$, 且潮 汐性淹水能够促进调落物分解 (图 2)。但 淹水条件和分解时间的交互作用对这两种 植物调落物的分解作用不显著 $(P>0.05)$ 。

\section{2 调落物重金属含量变化}

在不同淹水条件下, 芦苇调落物中

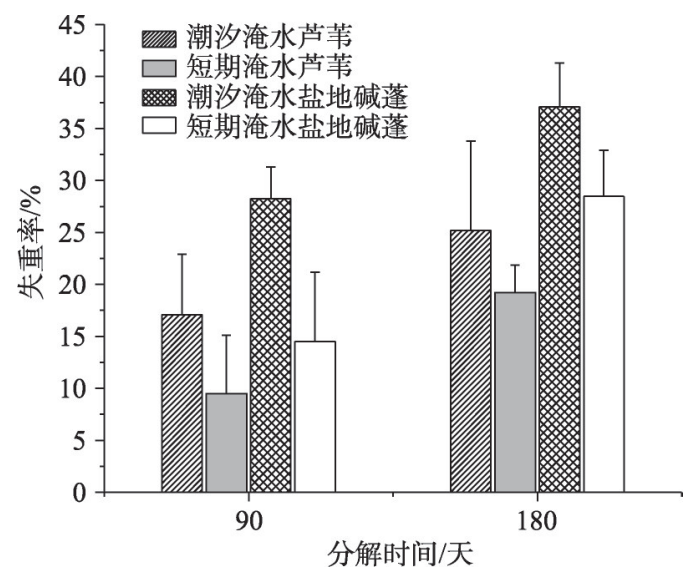

图 2 不同淹水条件下芦苇和盐地碱蓬 调落物失重率

Fig. 2 Mass loss of P. australis and S. salsa litters at different flooding levels

$\mathrm{As} 、 \mathrm{Cr} 、 \mathrm{Cu} 、 \mathrm{~Pb} 、 \mathrm{Zn}$ 等五种重金属的初始值分别为 $0.60 \mathrm{mg} / \mathrm{kg} 、 10.69 \mathrm{mg} / \mathrm{kg} 、 6.49 \mathrm{mg} / \mathrm{kg}$ 、 $12.73 \mathrm{mg} / \mathrm{kg}$ 和 $36.30 \mathrm{mg} / \mathrm{kg}$; 盐地碱蓬调落物的五种重金属的初始值分别为 $1.02 \mathrm{mg} / \mathrm{kg}$ 、 
表 1 淹水条件和分解时间对芦苇分解和重金属含量的双因素方差分析结果

Table 1 The two-AVONA analysis for the mass remaining and heavy metal concentration of $P$. australis

\begin{tabular}{ccccccc}
\hline 项目 & 残余质量 & $\mathrm{As}$ 含量 & $\mathrm{Cr}$ 含量 & $\mathrm{Cu}$ 含量 & $\mathrm{Pb}$ 含量 & $\mathrm{Zn}$ 含量 \\
\hline 淹水条件 & $0.011^{*}$ & $0.014^{*}$ & 0.230 & 0.914 & 0.161 & 0.130 \\
分解时间 & $0.001^{*}$ & $0.001^{*}$ & 0.937 & 0.302 & $0.000^{*}$ & $0.028^{*}$ \\
水淹条件×分解天数 & 0.743 & $0.000^{*}$ & $0.027^{*}$ & 0.006 & $0.000^{*}$ & $0.001^{*}$ \\
\hline
\end{tabular}

注: “表示淹水条件与分解时间的交互作用，下同。

表 2 淹水条件和分解时间对盐地碱蓬分解和重金属含量的双因素方差分析结果

Table 2 The two-AVONA analysis for the mass remaining and heavy metal concentration of $S$. salsa

\begin{tabular}{ccccccc}
\hline 项目 & 残余质量 & $\mathrm{As}$ 含量 & $\mathrm{Cr}$ 含量 & $\mathrm{Cu}$ 含量 & $\mathrm{Pb}$ 含量 & $\mathrm{Zn}$ 含量 \\
\hline 淹水条件 & $0.000^{*}$ & $0.002^{*}$ & 0.731 & $0.001^{*}$ & 0.128 & $0.001^{*}$ \\
分解时间 & $0.000^{*}$ & 0.508 & 0.523 & 0.422 & $0.000^{*}$ & 0.315 \\
水淹条件×分解天数 & 0.195 & 0.293 & 0.845 & 0.537 & $0.004^{*}$ & 0.642 \\
\hline
\end{tabular}

$9.26 \mathrm{mg} / \mathrm{kg} 、 10.29 \mathrm{mg} / \mathrm{kg} 、 9.93 \mathrm{mg} / \mathrm{kg}$ 和 $55.71 \mathrm{mg} / \mathrm{kg}$ 。由图3 可知, 两种淹水条件下芦苇 调落物分解 180 天后的 $\mathrm{Pb}$ 和 $\mathrm{Zn}$ 含量下降, $\mathrm{As} 、 \mathrm{Cr} 、 \mathrm{Cu}$ 的含量则增加; 潮汐淹水条件下 的芦苇调落物的五种重金属含量均高于短期淹水处理，且均有显著性差异 $(P<0.05)$ 。盐 地碱蓬调落物经 180 天分解后，两种淹水条件下的重金属含量总体呈上升变化趋势; 潮 汐淹水条件下的盐地碱蓬调落物中 $\mathrm{As} 、 \mathrm{Cu} 、 \mathrm{~Pb}$ 含量均较短期淹水处理高, 且两种淹水条
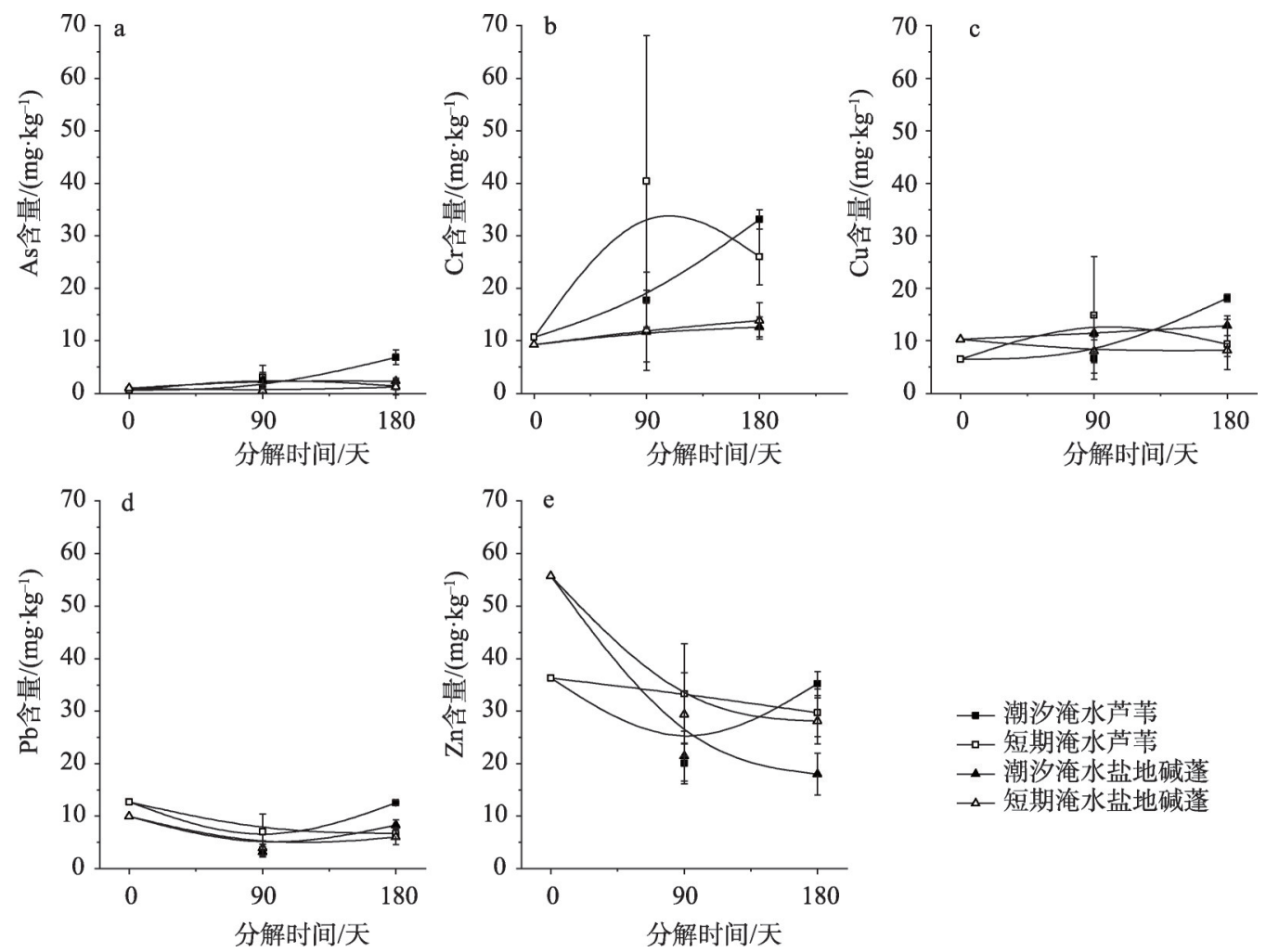

图 3 分解期间芦苇和盐地碱蓬凋落物重金属含量变化

Fig. 3 Variations of heavy metal contents for P. australis and S. salsa litters during decomposition 
件下 $\mathrm{Cu}$ 和 $\mathrm{Pb}$ 含量差异达到显著性水平 $(P<0.05)$ 。总体上, 潮汐淹水条件下的芦苇调落 物的各金属含量显著高于盐地碱蓬调落物 $(P<0.05)$ 。采用双因素方差分析检验了淹水条 件和分解时间对芦苇和盐地碱蓬调落物的重金属含量变化的影响（表1、表2）。结果显 示，二者交互作用对芦苇调落物的重金属含量有显著性影响 $(P<0.05)$, 盐地碱蓬调落物 中仅 $\mathrm{Pb}$ 含量达到显著性水平 $(P>0.05)$ 。

\section{3 不同淹水条件下芦苇和盐地碱蓬调落物重金属的释放与积累}

两种淹水条件下芦苇和盐地碱蓬调落物的 $\mathrm{Pb}$ 和 $\mathrm{Zn}$ 在分解期间均发生了不同程度的 净归还（图 4) 但没有达到显著性水平 $(P>0.05)$; 盐地碱蓬调落物中 $\mathrm{Pb}$ 和 $\mathrm{Zn}$ 的净归还 率整体上高于芦苇调落物。但芦苇调落物中的 $\mathrm{As}$ 和 $\mathrm{Cr}$ 以及盐地碱蓬调落物中的 $\mathrm{Cu}$ 均发 生了不同程度的积累。
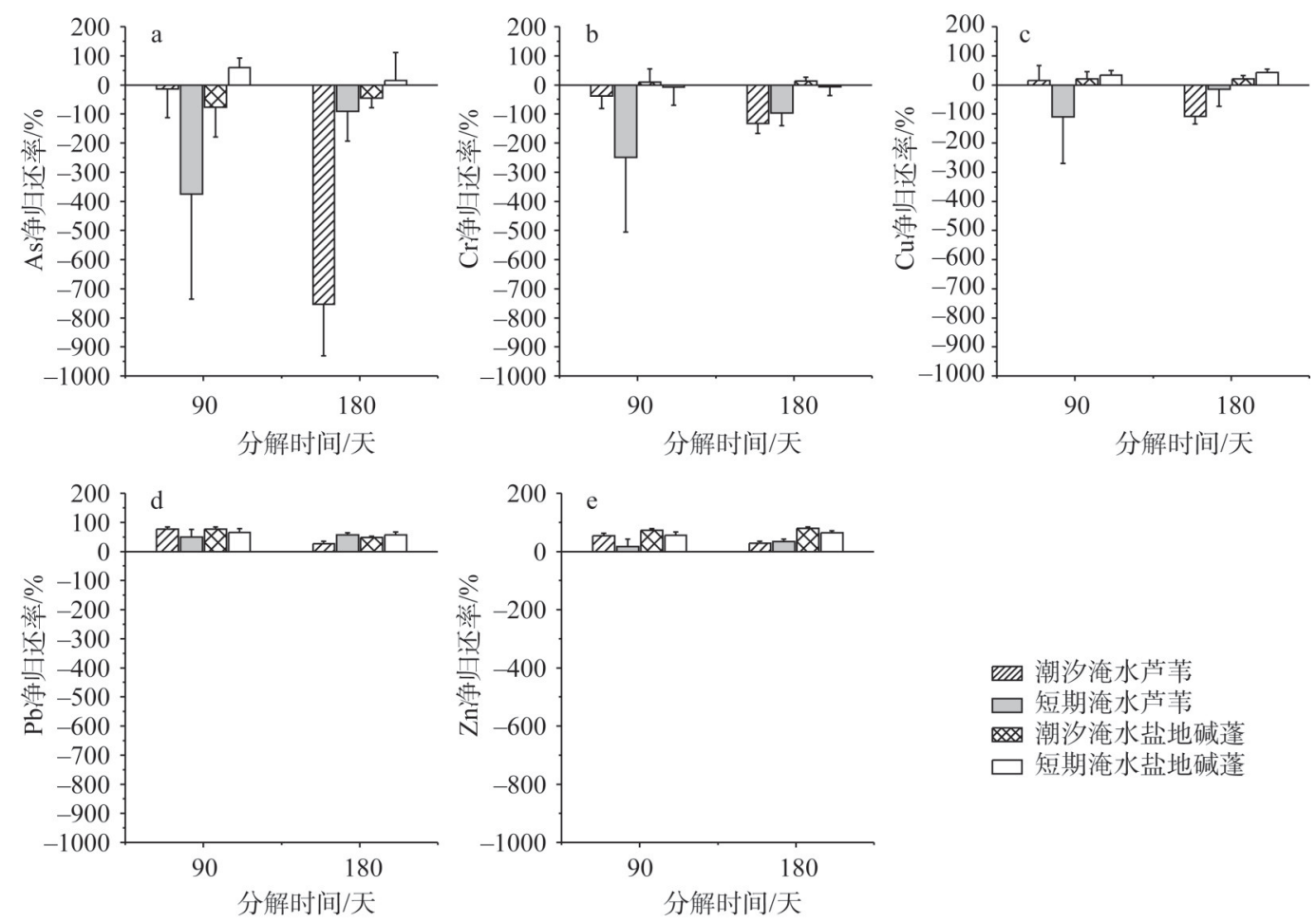

图 4 不同淹水条件下芦苇和盐地碱蓬调落物重金属净归还率

Fig. 4 Net return rates of heavy metals for P. australis and S. salsa litters in different flooding levels

\section{3 讨论}

本研究表明，两种淹水条件下，盐地碱蓬凋落物失重率均高于芦苇调落物 $(P<0.05)$; 与短期淹水相比, 潮汐淹水条件下的芦苇调落物失重率相对较高, 但未达到显著水平 $(P>0.05)$; 盐地碱蓬调落物在潮汐淹水条件下的失重率显著高于短期淹水湿地（ $P<0.05)$ 。 淹水条件和分解时间的交互作用对芦苇和盐地碱蓬调落物的分解速率均无显著性影响 $(P>0.05)$ 。相关研究表明, 调落物分解速率受到调落物基质质量和分解过程等外在环境 的影响, 其中调落物自身结构是影响其相对分解速率的决定性因素。芦苇的木质素含量 高于盐地碱蓬, 不易发生分解; 在两种淹水条件下, 芦苇的分解速率均低于盐地碱蓬, 
这与 Sun 等 ${ }^{[18]}$ 的研究结果相似。调落物分解速率同时还与其所在的分解环境和微生物活 性密切相关。潮汐作用增加了土壤含水量, 加速了调落物的淋溶损失, 致使可溶性物质 大量损失，所以分解速率较快。然而，经过 180 天分解后，潮汐性淹水对芦苇调落物的 分解速率影响不大, 这可能是由于过量的水分导致氧化还原电位降低, 氧气可利用性下 降, 使得微生物分解速率降低 ${ }^{[19]}$ 。潮汐性淹水条件下的芦苇和盐地碱蓬调落物在前 90 天 分解速率显著高于短期淹水处理 $(P<0.05)$ 。这是由于分解初期, 淍落物分解以淋溶为 主, 分解速率较快; 随着分解的进行, 调落物中如纤维素、木质素等难分解物质浓度增 加，分解受到抑制，导致分解速率明显减慢。

分解 180 天后，两种淹水条件下芦苇调落物的 $\mathrm{Pb}$ 和 $\mathrm{Zn}$ 含量降低，而 $\mathrm{As} 、 \mathrm{Cr}$ 和 $\mathrm{Cu}$ 的 含量增加; 且潮汐淹水条件下芦苇调落物的各金属含量均高于短期淹水处理。盐地碱蓬 调落物在两种淹水条件下经过分解后，各金属含量总体呈上升趋势。潮汐淹水条件下盐 地碱蓬调落物中 $\mathrm{As} 、 \mathrm{Cu}$ 和 $\mathrm{Pb}$ 的含量均高于短期淹水处理。潮汐性淹水条件下芦苇调落 物中各金属含量显著高于盐地碱蓬调落物 $(P<0.05)$ 。重金属含量的增加可以归因于多种 因素，如：难分解有机物质的被动吸收、微生物作用、水盐条件的变化等 ${ }^{[20]}$ 。已有研究 表明，在凋落物分解过程中，重金属通过与调落物有机物表面的被动吸收或微生物群落 的生理机制相关，并且当微生物调控金属时，调落物也可作为重金属的来源 ${ }^{[21-22]}$ 。在潮汐 性淹水条件下，受到咸淡水交互作用的影响，大量悬浮颗粒物絮凝、聚集、再悬浮，使 得凋落物吸收海水中重金属的机会增加 ${ }^{[23]}$ 。潮汐作用是影响湿地凋落物分解的一个重要 因素, 不仅影响凋落物质量, 还会导致温度、 $\mathrm{pH} 、 \mathrm{Eh}$ 、溶解氧浓度、盐度等环境因子的 变化, 进而影响其分解 ${ }^{[13,24]}$ 。

根据已有的研究可知，当元素损失率大于干物质重量损失率时，表明该元素的归还 途径主要是淋溶作用; 而当元素损失率小于干物质重量损失时，表明该元素有积累的趋

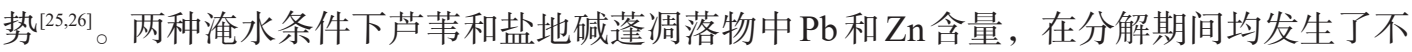
同程度的释放, 因此增加了区域湿地 $\mathrm{Pb}$ 和 $\mathrm{Zn}$ 污染的潜在风险。Tang 等 ${ }^{[27}$ 的研究已发现 黄河三角洲海水中有较高浓度的 $\mathrm{Zn}$ 水平。

调落物重金属的释放和积累水平较为复杂，这是因为重金属在调落物分解过程中的 释放或吸附积累主要包括两个过程：调落物氧化时释放重金属和调落物的有机物吸附重 金属 ${ }^{[20]}$ 。这两个过程受到水盐和污染等外界环境条件，以及分解袋孔径和植物调落物性 质等实验条件的影响使得重金属动态研究变得复杂化。

\section{4 结论}

（1）淹水条件和植被类型是影响湿地植物凋落物分解的重要因素。相对于短期淹水 处理, 潮汐淹水更有利于芦苇和盐地碱蓬调落物的分解; 在两种淹水条件下, 盐地碱蓬 调落物较芦苇调落物更易分解。

（2）湿地植物调落物在分解过程中重金属含量的变化受淹水条件和植被类型的影 响。与短期淹水相比, 潮汐淹水可促使芦苇和盐地碱蓬调落物在分解过程中吸附重金 属; 对于芦苇调落物而言, $\mathrm{As} 、 \mathrm{Cr}$ 和、 $\mathrm{Cu}$ 含量增加较为明显; 而潮汐淹水条件下的盐地 碱蓬调落物 $\mathrm{As} 、 \mathrm{Cu}$ 和 $\mathrm{Pb}$ 的含量均高于短期淹水处理。

（3）两种淹水条件下芦苇和盐地碱蓬调落物中 $\mathrm{Pb}$ 和 $\mathrm{Zn}$ 在分解期间均呈现出不同程 度的净归还，因此，应该对这两种重金属进行长期动态监测，并采取相应的措施降低其 
潜在生态风险。

\section{参考文献(References):}

[1] 王凤友. 森林调落量研究综述. 生态学进展, 1989, (2): 82-89. [WANG F U. Review on the study of forest litterfall. Advances in Ecology, 1989, (2): 82-89.]

[2] MOUGIN E, SEEN D L, RAMBAL S, et al. A regional Sahelian grassland model to be coupled with multispectral satellite data: I. Model description and validation. Remote Sensing of Environment. 1995, 52(3): 181-193.

[3] III F S C, MATSON P A, MOONEY H A. Principles of Terrestrial Ecosystem Ecology. New York: Springer, 2002: $369-397$.

[4] 向云, 程曼, 安韶山, 等. 延河流域不同立地条件下植物一枯落物一土壤生态化学计量学特征. 自然资源学报, 2015, 30(10): 1642-1652. [XIANG Y, CHENG M, AN S S, et al. Soil-plant-litter stoichiometry under different site conditions in Yanhe Catchment, China. Journal of Natural Resources, 2015, 30(10): 1642-1652.]

[5] 邓伟, 白军红. 典型湿地系统格局演变与水生态过程: 以黄淮海地区为例. 北京: 科学出版社, 2012: 236-238. [DENG W, BAI J H. Pattern Evolution of Typical Wetland System and Hydro-ecological Processes for Huang-Huai-Hai Region of China. Beijing: Science Press, 2012: 236-238.]

[6] 武海涛, 吕宪国, 杨青, 等. 三江平原典型湿地枯落物早期分解过程及影响因素. 生态学报, 2007, 27(10): 4027-4035. [WU H T, LYU X G, YANG Q, et al. Early-stage litter decomposition and its influencing factors in the wetland of the Sanjiang Plain, China. Acta Ecologica Sinica, 2007, 27(10): 4027-4035.]

[7] LU Q Q, BAI J H, GAO Z Q, et al. Spatial and seasonal distribution and risk assessments for metals in a Tamarix Chinensis Wetland, China. Wetlands, 2016, 36(1): 125-136.

[8] GAO X L, CHEN C T A. Heavy metal pollution status in surface sediments of the coastal Bohai Bay. Water Research, 2012, 46(6): 1901-1911.

[9] TEUCHIES J, JACOBS S, OOSTERLEE L, et al. Role of plants in metal cycling in a tidal wetland: Implications for phytoremidiation. Science of the Total Environment, 2013, 445-446: 146-154.

[10] SUNTORNVONGSAGUL K, BURKE D J, HAMERLYNCK E P, et al. Fate and effects of heavy metals in salt marsh sediments. Environmental Pollution, 2007, 149(1): 79-91.

[11] 严莉, 李龙山, 倪细炉, 等. 5 种湿地植物对土壤重金属的富集转运特征. 西北植物学报, 2016, 36(10): 2078-2085. [YAN L, LI L S, NI X L, et al. Accumulation of soil heavy metals in five species of wetland plants. Acta Botanica Boreali-Occidentalia Sinica, 2016, 36(10): 2078-2085.]

[12] BAI J H, XIAO R, ZHANG K J, et al. Arsenic and heavy metal pollution in wetland soils from tidal freshwater and salt marshes before and after the flow-sediment regulation regime in the Yellow River Delta, China. Journal of Hydrology, 2012, 450-451(11): 244-253.

[13] 陆珺, 张银龙, 徐明喜. 不同水淹条件下芦苇立枯体的分解及营养动态. 林业工程学报, 2011, 25(4): 42-45. [LU J, ZHANG Y L, XU M X. Litter decomposition and nutrient dynamics of Phragmites australis in different flooding levels. Journal of Forestry Engineering, 2011, 25(4): 42-45.]

[14] 于君宝, 董洪芳, 王慧彬, 等. 黄河三角洲新生湿地土壤金属元素空间分布特征. 湿地科学, 2011, 9(4): $297-304$. [YU J B, DONG H F, WANG H B, et al. Spatial distribution characteristics of metals in new-born coastal wetlands in the Yellow River Delta. Wetland Science, 2011, 9(4): 297-304.]

[15] BAI J H, XIAO R, CUI B S, et al. Assessment of heavy metal pollution in wetland soils from the young and old reclaimed regions in the Pearl River Estuary, South China. Environmental Pollution. 2011, 159(3): 817-824.

[16] 王红, 宫鹏, 刘高焕. 黄河三角洲多尺度土壤盐分的空间分异. 地理研究, 2006, 25(4): 649-658. [WANG H, GONG P, LIU G H. Multi-scale spatial variations in soil salt in the Yellow River Delta. Geographical Research, 2006, 25(4): 649-658.]

[17] OLSON J S. Energy storage and the balance of producers and decomposers in ecological systems. Ecology, 1963, 44(2): 322-331.

[18] SUN Z G, MOU X J, SUN W L. Decomposition and heavy metal variations of the typical halophyte litters in coastal marshes of the Yellow River Estuary, China. Chemosphere, 2016, 147: 163-172.

[19] BerG B, MCCLAUGHERTY C. Plant Litter, Decomposition. Humus Formation, Carbon Sequestration. New York: Springer, 2003: 102-110.

[20] DU L G, VAN R G, TACK F M, et al. Metal accumulation in intertidal litter through decomposing leaf blades, sheaths and stems of Phragmites australis. Chemosphere, 2006, 63(11): 1815-1823.

[21] GADD G M. Metals and microorganisms: A problem of definition. Fems Microbiology Letters, 1992, 100(1-3): 197-203. 
[22] LEDIN M. Accumulation of metals by microorganisms: Processes and importance for soil systems. Earth Science Reviews, 2000, 51(1): 1-31.

[23] WEIS J S, WEIS P. Metal uptake, transport and release by wetland plants: Implications for phytoremediation and restoration. Environment International, 2004, 30(5): 685-700.

[24] 杨丹, 谢宗强, 㚞大勇, 等. 三峡水库蓄水对消落带土壤 $\mathrm{Cu} 、 \mathrm{Zn} 、 \mathrm{Cr} 、 \mathrm{Cd}$ 含量的影响. 自然资源学报, 2018, 33(7): 1283-1290. [YANG D, XIE Z Q, FAN D Y, et al. The effect of water fluctuation on the contents of soil Cu, Zn, Cr and $\mathrm{Cd}$ at the riparian area of Three Gorges Reservoir. Journal of Natural Resources, 2018, 33(7): 1283-1290.]

[25] VALK A G V D, ATTIWILl P M. Above- and below- round litter decomposition in an Australian salt marsh. Austral Ecology, 2010, 8(4): 441-447.

[26] 卢杰, 张硕新, 方江平, 等. 藏东南高山松天然林水文过程中养分元素变化特征. 自然资源学报, 2016, 31(1): 151162. [LU J, ZHANG S X, FANG J P, et al. Variation characteristics of nutrient elements through hydrological processes in Pinus densata natural forest of Southeast Tibet. Journal of Natural Resources, 2016, 31(1): 151-162.]

[27] TANG A, LIU R, LING M, et al. Distribution characteristics and controlling factors of soluble heavy metals in the Yellow River Estuary and adjacent sea. Procedia Environmental Sciences, 2010, 2(1): 1193-1198.

\title{
Litter decomposition and heavy metal return characteristics of Phragmite australis and Suaeda salsa under different flooding conditions in the Yellow River Delta, China
}

\author{
GUAN Ya-nan ${ }^{1,2}$, BAI Jun-hong ${ }^{1}$, WANG Wei ${ }^{1}$, WANG Da-wei ${ }^{1}$, YIN Shuo ${ }^{1}$ \\ (1. State Key Laboratory of Water Environment Simulation, School of Environment, Beijing \\ Normal University, Beijing 100875, China; 2. College of Chemistry and Material \\ Science, Heibei Normal University, Shijiazhuang 050020, China)
}

\begin{abstract}
The remained litter mass, and the contents of $\mathrm{As}, \mathrm{Cr}, \mathrm{Cu}, \mathrm{Pb}$, and $\mathrm{Zn}$ in the litters of Phragmites australis and Suaeda salsa under different flooding conditions in the Yellow River Delta were determined to investigate the litter decomposition rates and heavy metal return characteristics. Results showed that the decomposition of $S$. salsa litters was significantly faster than that of $P$. australis litters $(P<0.05)$, and the decomposition under tidal flooding conditions was faster than that under the short-term flooding conditions. In terms of $P$. australis litters, their contents of $\mathrm{As}, \mathrm{Cr}$ and $\mathrm{Cu}$ were higher compared to the initials, and these heavy metals contents of $P$. australis litters under tidal flooding conditions were higher than those under short-term flooding conditions. For $S$. salsa litters, all heavy metals exhibited an increase in the study, and the contents of $\mathrm{As}, \mathrm{Cu}$ and $\mathrm{Pb}$ under tidal flooding conditions were significantly higher than those under the short-term flooding conditions $(P<0.05) . \mathrm{Pb}$ and $\mathrm{Zn}$ were released during the decomposition for both $P$. australis and $S$. salsa litters. The findings of this study contributed to further studies on the influences of the tidal waves on the litter decomposition and metal returns in the Yellow River Delta.
\end{abstract}

Keywords: litters; flooding conditions; Phragmite australis; Suaeda salsa; decomposition; heavy metals 